\title{
The Determination of Promising Mineral Zones in 1:100,000 Varamin Sheet Based on Geochemical Studies (Heavy Minerals)
}

\author{
Seyyed Reza Mortazavi, Ghodratollah Mohammadi \\ Department of Mining Engineering, Islamic Azad University, South Tehran Branch, Tehran, Iran \\ Email: SeyyedReza.Mortazavi@chmail.ir, gh_Mohammadi@azad.ac.ir
}

Received 1 May 2016; accepted 7 August 2016; published 10 August 2016

Copyright (C) 2016 by authors and Scientific Research Publishing Inc.

This work is licensed under the Creative Commons Attribution International License (CC BY). http://creativecommons.org/licenses/by/4.0/

c) (i) Open Access

\begin{abstract}
In many parts of the world, data obtained from geochemical exploration of stream sediments are integrated with geological and geophysical data as one of the most efficient methods of exploring potential deposits at regional and semi-detailed scales. The aim of regional investigation is to study large areas to identify anomalies that might have been arisen from increased concentrations of an element or some elements in a region. A total of $\mathbf{7 8}$ geochemical samples were taken from Varamin sheet to identify regions of anomalies. The following information was used to perform a detailed geochemical exploration, in particular for geochemical sampling. 1) 1:100,000 geological map of Varamin. 2) 1:50,000 topographic maps of the region. 3) 1:100,000 airborne geophysical map of the region to locate shallow intrusions and hidden faults. The sampling network was designed using the above data and the analysis of 1:500,000 topographic maps. The sampling density was higher around faults and apparent and hidden intrusions, and lower in plains and lowlands.
\end{abstract}

\section{Keywords}

Geochemical, Heavy Minerals, Varamin, Promising Mineral, Determination

\section{Introduction}

The 1:100,000 map of Varamin includes southeast of Tehran province with eastern longitudes of $30^{\circ} 51^{\prime} 51$ " and northern latitudes of $30^{\circ} 35^{\prime} 35^{\prime \prime}$. Varamin is one of the cities in Tehran province and is limited to Damavand and Shemiranat from north, Tehran and Rey from west, Qom from south and Varamin from east. Varamin consists of three towns including Varamin, Pishva and Gharchak. The central part of the city is plain, the southern part is desert and the northern part is limited to southern highlands of the Alborz mountain range. With a height of

How to cite this paper: Mortazavi, S.R. and Mohammadi, G. (2016) The Determination of Promising Mineral Zones in 1:100,000 Varamin Sheet Based on Geochemical Studies (Heavy Minerals). Open Journal of Geology, 6, 745-756. 
1408 and $1708 \mathrm{~m}$ and a distance of 16 and $20 \mathrm{~km}$ from Varamin, Parchin and Jelvik mountains are the nearest mountains to the north of Varamin, respectively. Ghareaghaj Highlands are located $25 \mathrm{~km}$ from northeast of Varamin. Among the other mountains of this region are, Mount Gach near Pishva Village, Mount Sorkh, Siyahkuh on the south of Varamin sheet, Mount Makresh, Mount Sharifeh, Mount Gorgan, Mount Hajiha, Mount Dahaneh, Mount Koolik, Mount Dogoosh, and Mount Hamamak. Varamin has a mild and dry climate, but the southern part has a warm and dry climate due to being located on the edge of a desert.

\section{Geomorphology}

The region includes flat and mountain parts. Mountains have been emerged as a result of structural processes, especially the folding of Tertiary sediments (Berberian and King, 1981). The study area is located in the Central Iran Zone in terms of structural divisions [1]. The most important rock outcrops are merely located in three points, i.e. the central and eastern parts of the sheet at Mount Sorkh, Mount Makresh and Mount Gach, the northern parts of Siahkuh in the south of this region and northeast of Hamamak, Dogoosh, Dahaneh, Koolic, Hajiha, Gorgan and Sharifeh mountains. The rock units are composed of lava and Eocene pyroclastic rocks (including basalt, andesite, trachybasalt, mega-porphyry, and acid breccia tuffs), clastic and marl sediments, Oligocene volcanic rocks, limestone, marl and Oligo-Miocene gypsum, limestone marl, sandstone, Miocene gypsum, conglomerates, Pliocene marl and conglomerates [2].

\section{Structural Geology}

Structural geology of the region in Central Iran Zone shows that Eocene tectonic movements had led to a variety of intermediate to basic volcanic lava in the middle and southern parts of the region. These movements in the next developed stages led to the formation of destructive and sedimentary units as well as marl, red and gypsum-bearing marl, gypsum and shale (Lower Red Formation equivalent). Miocene tectonic movements as epeirogenic (vertical) movements led to changes in the depth of sedimentary basin. These changes led to the formation of sandstone marl sediments with a thickness of several thousand meters in shallow marine and lagoon environments(outside the sheet in the north of Varamin). Some tectonic movements equivalent to final Alpine orogeny phase led to inconsistent Pliocene clastic deposits on the older units. The other feature of the region is the changing of the strata's horizontality and the inconsistent placement of young Quaternary deposits on older units with a gentle gradient [3].

\section{Faults and Folds}

1) With a length of $34 \mathrm{~km}$ and N30E direction, Pishva fault is located in the southeast of Varamin. This thrust fault with a northeast slope clearly cuts the Quaternary deposits and forms a boundary between the mountain and plain regions in Pishva. Currently, a number of houses have been constructed on Pishva fault.

2) Parchin fault is located in the south of Parchin and on the outlet of Jajrood River to Varamin plain on the border between Hezardarreh alluvial formation and plain. Parchin fault cuts the alluvial sediments in the western part of Jajrood River. Parchin fault with a NW-SE direction includes thrust faults with a northern slope.

3) The impacts of Kahrizak fault can be seen in the south of Rey as a long eastern wall with a length of $40 \mathrm{~km}$. Part of the fault is seen in the south of Ghaleno in Varamin road. With a thrust mechanism Kahrizak fault is inclined toward north.

4) Varamin fault with a NE direction is located in the north of Varamin with many bends toward the west. After passing through the foothills of Takht-e Rostam and Mount Sorkh in the southeast of Varamin, it reaches Pishva fault. The length of Varamin fault from the north of Deh Namak in the east to the southwest of the Mount Sorkh and the Shour (Abhar) River in the west is about $70 \mathrm{~km}$.

\section{Mineral Signs in the Region}

Several types of minerals can be seen in the Varamin map, some of which have been used and exploited. These include:

1) Sodium sulfate which is locally found in the lowlands and plains as small bumps where $\mathrm{Na}_{2} \mathrm{SO}_{4}$ is formed due to the evaporation of water containing this mineral. Sodium sulfate is currently exploited in proper sea- 
sons and in different areas of the sheet such as Mohammad Abad, Razi Abad, Karimabad, Sharif Abad, Asqarabad, Shekarabad, Deh Shour and Yousef Abad [4].

2) Strontium sulfate horizons in the area are widely spread as celestite with low impurities of calcite and quartz between the calcareous sequences of Qom Formation. The mineral is concentrated as nodules and pebbles (with a diameter of 30 to $40 \mathrm{~cm}$ ) between limestone or marl layers in one or more horizons. This horizon that also exists in Varamin continues to Jandagh.

3) Limestone and marls of the Qom Formation consist of gypsum layers with outcrops in some places including Mount Gach, Mount Sorkh and the south of Varamin sheet (Siyahkuh). In some cases, gypsum and limestone are used as pebble. Large deposits of sand and gravel have been exploited on the Sharif Abad-Tehran road near Pakdasht [5].

\section{Discussion}

The best places to take samples in regional geochemical surveys are customarily stream sediments which, in turn, depend on different weather, geological, topographical, and mineralization conditions, as well as waterway slopes and the overall slope of the region. Rainfall in different environments causes varying degrees of mechanical and chemical erosion and thereby varying levels of sediment transports. The type and severity of erosion and sediment transport is heterogeneous in regions with different morphologies.

The full study of drainage basins for designing and sampling allows final assessment and access to information of upstream basins as a guide to detect possible anomalies. Potential areas (secondary deposit zones) are clearly formed when mineralization (initial zones) occurs in an environment where sediments are originated. Therefore, in regional-scale geochemical explorations, mineralization process can be identified with stream sediment sampling and detection of secondary zones. In this study, by studying 1:50,000 topographic maps of the region, the watershed basins were studied and the waterway system was completed. Then, using the geological map of the region considering potentially mineralized rock units, intrusions, important crosses, fault systems and old and active mines were identified and the geography of the area was studied using the airborne geomagnetic map. Geochemical samples were taken from waterways with a sieve of 80 mesh size. This is also considered as a preliminary preparation step [6]. The weight of sample was about $150 \mathrm{~g}$. In the case of wet environment, the samples were not sieved to be prepared after drying in the camp. Notable events in the field including alteration, mineralization, major faults, old and actives mines not registered in the geological maps were also considered. Data processing is valid when the experimental error(duplicate sample analysis) is less than $10 \%$. With regard to complementary methods including heavy mineral studies and anomaly control and the consistency or inconsistency of geochemical anomalies and the results of the data processing, the accuracy of analysis and data processing can be improved. The stages of data processing include documentation of raw data received from the laboratory, identification and replacement of censored data, univariate and multivariate statistical analysis to identify values outside category to provide desirable results in the form of graphs and tables. In 1:100,000 sheet of Varamin, a considerable part of the region includes Gharchak and Javad Abad. Each of these towns consists of a wide range of other rural and urban areas including gardens, farms and military zones. Thus, sampling design only covers sections of outcropped rock units. In this sheet, rocky outcrops can be merely seen in three regions [7].

1) The northeast of the sheet on the Tehran-Mashhad main road including watersheds that are generally parallel and often pass through the sediments and sandstone formations.

2) Central and eastern parts of the sheet in the east of Pishva which are mainly covered by the middle and evaporite sediments of the Qom Formation to the upper late Oligocene and the Lower Red Formation including marl sediments and upper Oligocene conglomerates and the Lower Red Formation which includes deposits of marl and lower Oligocene conglomerate. The access road to the above area is Varamin-Pishva road and then through a dirt road next to the railway [8].

3) The outcrops of Eocene formations in the south of sheet mainly include volcanic rocks, tuffs and gypsum marl which form highlands called Siyahkuh. The rest of the region includes cities, villages and salt plains in the Ghaleh Bandar and Javad Abad sheets. Some elements such as Nb, Mo, Sb, Nd, Sm, En, U, Au and W with more than 50 to 100 percent of censored values have been actually removed from data processing.

Table 1, due to the lack of logical connection between some elements and rock formations in the study area, $\mathrm{Ga}, \mathrm{Ni}, \mathrm{Co}, \mathrm{Cr}$, La were not processed. The concentration of some elements such as $\mathrm{Y}, \mathrm{Cu}, \mathrm{Ce}, \mathrm{Yb}$ and $\mathrm{Tl}$ was so high that anomaly assumption does not apply. After a careful look at values and histograms, Ga, Y, Nb, Mo, 
Table 1. Names decomposed elements, the number and percentage of censored data they.

\begin{tabular}{|c|c|c|c|c|c|c|c|c|c|c|c|}
\hline \multicolumn{12}{|c|}{ VARAMIN SENSORED DATA } \\
\hline & $\mathrm{V}$ & $\mathrm{Cr}$ & Co & $\mathrm{Ni}$ & $\mathrm{Cu}$ & $\mathrm{Zn}$ & $\mathrm{Ga}$ & $\mathrm{Sr}$ & $\mathrm{Y}$ & $\mathrm{Zr}$ & $\mathrm{Nb}$ \\
\hline \multirow[t]{2}{*}{ NO.OF SENSORED } & 0 & 0 & 0 & 0 & 0 & 0 & 0 & 0 & 0 & 0 & 82 \\
\hline & Mo & $\mathrm{Sb}$ & Cs & $\mathrm{Ba}$ & $\mathrm{La}$ & $\mathrm{Nd}$ & $\mathrm{Sm}$ & $\mathrm{Eu}$ & $\mathrm{Tb}$ & $\mathrm{Yb}$ & Hf \\
\hline \multirow[t]{2}{*}{ NO.OF SENSORED } & 84 & 85 & 82 & 0 & 5 & 84 & 46 & 83 & 3 & 0 & 2 \\
\hline & $\mathrm{Tl}$ & $\mathrm{Pb}$ & $\mathrm{U}$ & $\mathrm{P}$ & $\mathrm{Ti}$ & $\mathrm{Mn}$ & S & As & $\mathrm{Ce}$ & $\mathrm{Au}$ & W \\
\hline NO.OF SENSORED & 3 & 0 & 85 & 0 & 0 & 0 & 0 & 0 & 0 & 80 & 67 \\
\hline \multicolumn{12}{|c|}{ NO.OF SENSORED DATA PER PERCENT } \\
\hline & $\mathrm{V}$ & $\mathrm{Cr}$ & Co & $\mathrm{Ni}$ & $\mathrm{Cu}$ & $\mathrm{Zn}$ & $\mathrm{Ga}$ & $\mathrm{Sr}$ & $\mathrm{Y}$ & $\mathrm{Zr}$ & $\mathrm{Nb}$ \\
\hline \multirow[t]{2}{*}{ \% OF SENSORED } & 0.0 & 0.0 & 0.0 & 0.0 & 0.0 & 0.0 & 0.0 & 0.0 & 0.0 & 0.0 & 96.5 \\
\hline & Mo & $\mathrm{Sb}$ & Cs & $\mathrm{Ba}$ & $\mathrm{La}$ & Nd & $\mathrm{Sm}$ & $\mathrm{Eu}$ & $\mathrm{Tb}$ & $\mathrm{Yb}$ & $\mathrm{Hf}$ \\
\hline \multirow[t]{2}{*}{ \% OF SENSORED } & 98.8 & 100.0 & 96.5 & 0.0 & 5.9 & 98.8 & 54.1 & 97.6 & 3.5 & 0.0 & 2.4 \\
\hline & $\mathrm{Tl}$ & $\mathrm{Pb}$ & $\mathrm{U}$ & $\mathrm{P}$ & $\mathrm{Ti}$ & $\mathrm{Mn}$ & S & As & $\mathrm{Ce}$ & $\mathrm{Au}$ & W \\
\hline \% OF SENSORED & 3.5 & 0.0 & 100.0 & 0.0 & 0.0 & 0.0 & 0.0 & 0.0 & 0.0 & 94.1 & 78.8 \\
\hline
\end{tabular}

Sb, Cs, La, Nd, Sm, En, Tb, Yb, Tl, U, Au and W were removed from data processing. Potential mineralization and geology of the study area show that such evaporite and sandstone formations are expected to include evaporite deposits of gypsum, celestite and barite [9].

Since celestite mineralization is observed along the Garmsar-Tehran route, the presence of this element in evaporite formations in Varamin sheet seems to be logical. A closer look at the data demonstrated that a specific kind of enrichment could be seen in this element, in a way that the minimum and maximum concentration of Sr in the sample was 359 and 6821 ppm, respectively. The other element is sulfur. While this element is usually less important in geochemical exploration in some areas, however, sulfur map was also drawn due to the destructive and evaporite formations in the study area and the coexistence of sulfur and strontium. Another element that suggests anomaly is zirconium. Accordingly, Zr map was also drawn. Therefore, anomaly maps were prepared only for S, Sr and Zr to be used in subsequent data processing (Table 2).

\section{Univariate Statistical Studies}

In geochemical studies, any element, oxide or compound that is analyzed is considered as a variable. In univariate statistical studies, the values of a variable are processed regardless of other variables. Due to the low number of elements due to the low amount of data that are not considered as geochemical anomalies ( $\mathrm{Zn}, \mathrm{Ba}, \mathrm{Sr})$, simple univariate studies were conducted in Varamin sheet on the basis of averages (X) and standard deviation (Stdev). Finally, abnormalities were separated based on $X+S, X+2 S, X+3 S$ and the maps were drawn. For a better understanding of the regional data, histograms of raw and normal data were drawn for some elements. As can be seen, most elements naturally have a normal histogram. Statistically, this means the lack of significant anomaly in the study area (Figure 1).

\section{Geochemical Anomalies Map}

Efforts have been made to explain the anomaly map to provide relatively concise and complete description of the content of each element, exact address of anomalies, number and position of the anomaly, intensity and relative severity of anomalies, placement of geochemical anomalies on fractured and faulted zones, rock units and geological structures. Control step plays an undeniable role in examining the accuracy of anomalous areas defined for each element (or a set of elements). At this stage of field operations, observations of explorers in combination with geological, tectonic, mineralization and alteration phenomena will clear many unusual geochemical behaviors through interpretation of the anomalous areas. Samples of heavy mineral deposits in anomalies and lithogeochemical samples of the altered and mineralized areas are very helpful in the analysis of the proposed areas. The degree and intensity of anomalies were determined given the number of anomalous samples within the anomaly and the sample grade in the triple range of anomalies. Most importantly, the obtained data 
Table 2. Statistical values for selected elements in varamin.

\begin{tabular}{|c|c|c|c|c|c|c|c|c|c|}
\hline \multicolumn{10}{|c|}{ Statistics } \\
\hline & $\mathrm{V}$ & CR & $\mathrm{CO}$ & NI & $\mathrm{CU}$ & $\mathrm{ZN}$ & SR & ZR & BA \\
\hline $\mathrm{N}$ & 85.0 & 85.0 & 85.0 & 85.0 & 85.0 & 85.0 & 85.0 & 85.0 & 85.0 \\
\hline Mean & 84.4 & 77.5 & 10.7 & 67.8 & 32.6 & 58.0 & 883.4 & 225.8 & 728.3 \\
\hline Std. Error of Mean & 1.8 & 1.9 & 0.3 & 0.7 & 0.5 & 0.9 & 107.1 & 8.5 & 18.8 \\
\hline Median & 82.9 & 75.5 & 10.7 & 68.3 & 32.7 & 57.8 & 580.0 & 207.4 & 702.8 \\
\hline Mode & 85.1 & 62.7 & 8.2 & 67.8 & 32.7 & 50.1 & 642.0 & 173.1 & 663.8 \\
\hline Std. Deviation & 16.4 & 17.3 & 3.0 & 6.3 & 4.8 & 8.2 & 987.0 & 78.1 & 173.1 \\
\hline Variance & 268.2 & 298.1 & 8.9 & 39.8 & 22.6 & 67.7 & $974,093.7$ & 6098.3 & $29,956.4$ \\
\hline Skewness & 1.6 & 1.3 & 0.4 & -0.4 & 0.2 & 0.3 & 4.2 & 4.8 & 1.1 \\
\hline Std. Error of Skewness & 0.3 & 0.3 & 0.3 & 0.3 & 0.3 & 0.3 & 0.3 & 0.3 & 0.3 \\
\hline Kurtosis & 7.5 & 3.6 & -0.2 & 2.8 & 0.9 & -0.1 & 21.0 & 27.7 & 2.8 \\
\hline Std. Error of Kurtosis & 0.5 & 0.5 & 0.5 & 0.5 & 0.5 & 0.5 & 0.5 & 0.5 & 0.5 \\
\hline Minimum & 46.1 & 43.7 & 4.9 & 46.7 & 20.3 & 38.6 & 287.3 & 160.6 & 396.5 \\
\hline Maximum & 168.0 & 151.0 & 18.0 & 88.1 & 47.2 & 79.8 & 6821.0 & 743.0 & 1449.0 \\
\hline \multicolumn{10}{|c|}{ Statistics } \\
\hline & $\mathrm{HF}$ & PB & $\mathrm{P}$ & TI & MN & S & AS & CE & \\
\hline $\mathrm{N}$ & 85.0 & 85.0 & 85.0 & 85.0 & 85.0 & 85.0 & 85.0 & 85.0 & \\
\hline Mean & 8.4 & 11.2 & 650.4 & 3401.1 & 761.6 & 1659.1 & 9.4 & 91.4 & \\
\hline Std. Error of Mean & 0.3 & 0.5 & 7.0 & 63.6 & 13.0 & 355.4 & 0.1 & 1.5 & \\
\hline Median & 8.2 & 11.0 & 650.9 & 3409.7 & 781.1 & 942.0 & 9.3 & 90.1 & \\
\hline Mode & 5.1 & 13.0 & 650.9 & 1933.7 & 721.5 & 128.7 & 8.7 & 80.4 & \\
\hline Std. Deviation & 2.7 & 4.5 & 64.6 & 586.7 & 119.6 & 3276.6 & 1.4 & 13.9 & \\
\hline Variance & 7.5 & 20.1 & 4178.3 & $344,240.8$ & $14,301.2$ & $10,735,914.1$ & 1.9 & 192.0 & \\
\hline Skewness & 0.9 & 2.3 & -0.1 & 1.3 & 0.0 & 6.2 & 2.2 & 0.7 & \\
\hline Std. Error of Skewness & 0.3 & 0.3 & 0.3 & 0.3 & 0.3 & 0.3 & 0.3 & 0.3 & \\
\hline Kurtosis & 1.8 & 9.1 & 0.2 & 7.6 & 1.7 & 46.8 & 8.5 & 2.8 & \\
\hline Std. Error of Kurtosis & 0.5 & 0.5 & 0.5 & 0.5 & 0.5 & 0.5 & 0.5 & 0.5 & \\
\hline Minimum & 4.0 & 4.1 & 478.6 & 1933.7 & 416.2 & 128.7 & 6.9 & 57.9 & \\
\hline Maximum & 19.3 & 32.9 & 812.2 & 6380.5 & 1142.1 & $27,483.0$ & 15.9 & 148.0 & \\
\hline
\end{tabular}

were generally low for these three elements, especially for zinc. Except two samples, the rest of results are not significant. The geochemical anomalies for above elements are summarized in the following table according to the maps:

- Raw data histogram of some elements in the 1:100,000 Varamin sheet.

- Histograms of normalized data for abnormal elements in the Varamin sheet.

Heavy mineral studies include sampling from low sorted alluvial deposits, washing and concentration, separation with heavy solution, magnetic separation and microscopic study of the remaining components. Deposits originating from the upstream rock masses, if did not form a placer deposit formation of one or more types of minerals, can be used as an exploration key tool along with or without geochemical exploration (Figure 2).

Using this exploration logic in the 1:100,000 Varamin sheet, a total of 14 heavy mineral sampling stations were selected in addition to the designed geochemical samples. After sampling and preparation procedures, the samples were sent to the laboratory for heavy mineral studies (Figures 3-6). 

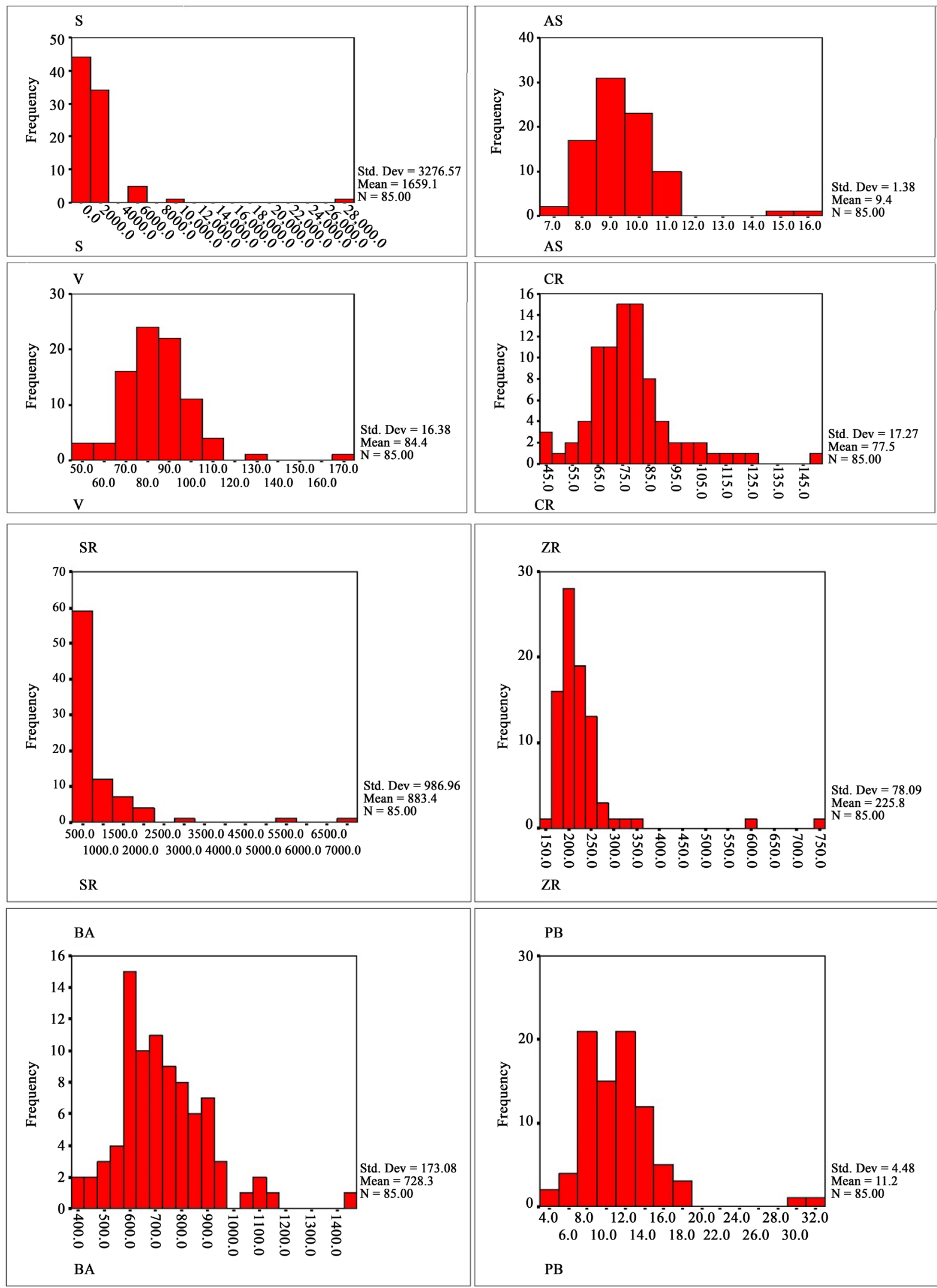

Figure 1. Raw data histogram on the sheet elements Varamin. 

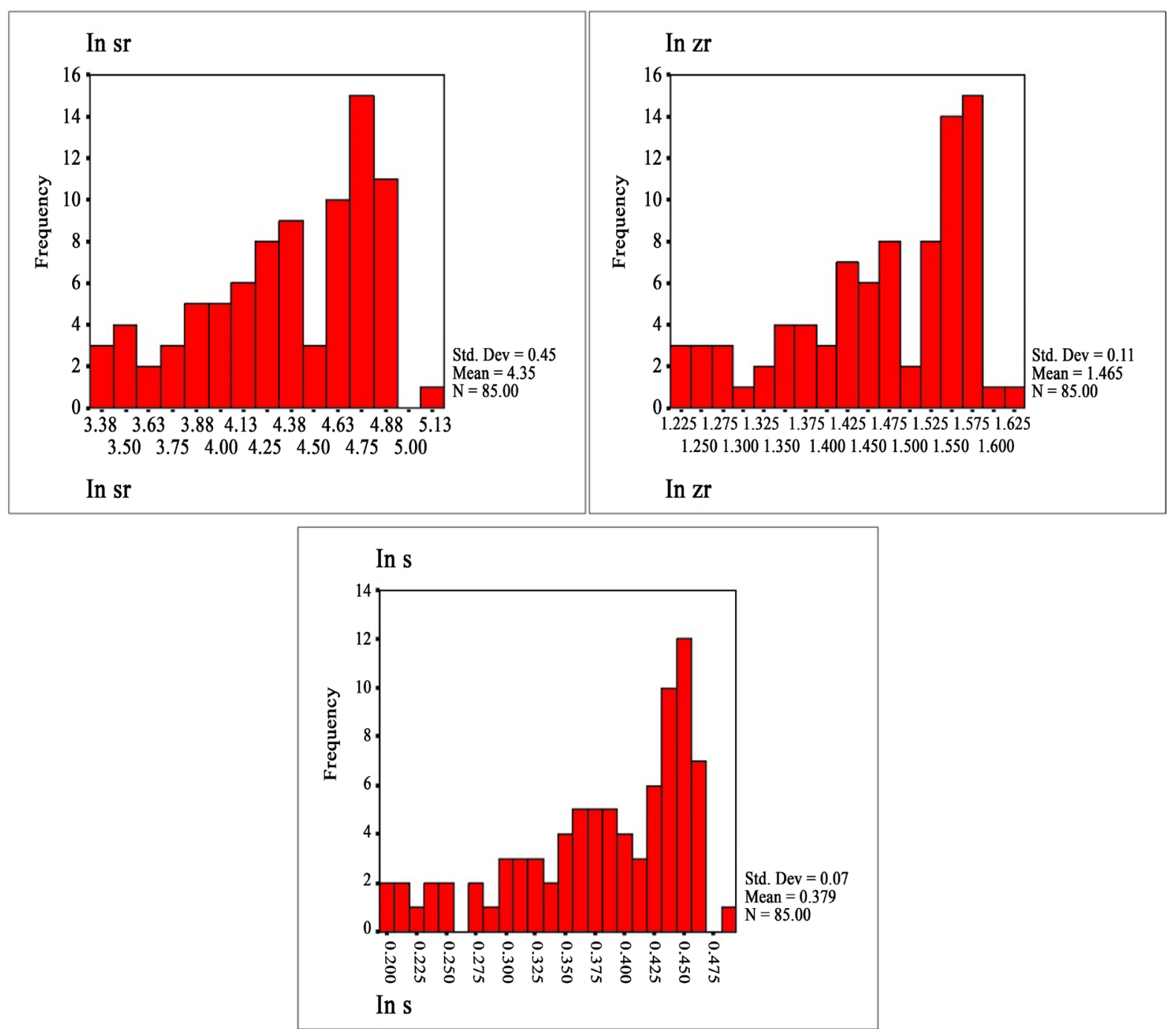

Figure 2. Normal data histogram on the sheet elements Varamin.

\section{Conclusions and Suggestions}

1) According to studies, the geochemical data should be integrated with available information to reach a higher reliability. This introduction just includes geochemical, heavy mineral, mineralized samples and field observations which most of them do not have the potential to continue exploration.

2) More than $75 \%$ of Varamin sheet area is covered by thick deposits of fine clay providing a suitable environment for agriculture. High concentration of strontium is due to outcrops of destructive and evaporite formations like gypsum, marl and clay sandstone.

3) Sulfur anomaly is due to the presence of salt plains where sodium sulfate mining is prevalent.

4) The study area is mainly covered by sand (with silt size) and fine shear and normal conglomerates. Due to the lack of outcrop or contact with internal or external igneous rocks, no sign of mineralization is observed.

5) Generally, Varamin sheet is not suggested for semi-detailed or detailed exploration.

6) The anomalies of Sr, Zr and S were controlled. The sulfur anomaly is traditionally used to exploit sodium sulfide. In addition, $\mathrm{Zr}$ anomaly has been observed in conglomerate formations of Sharif Abad sheet. Accordingly, manual preparation of samples for analysis or polished sections is meaningless.

7) Sr anomaly is located in the north of Ghale Boland sheet in a region with a small outcrop of evaporite formations where the highest concentration of strontium is much lower than its minimum allowable concentration in deposits of this element. No obvious Sr mineralization was observed in the study area. 


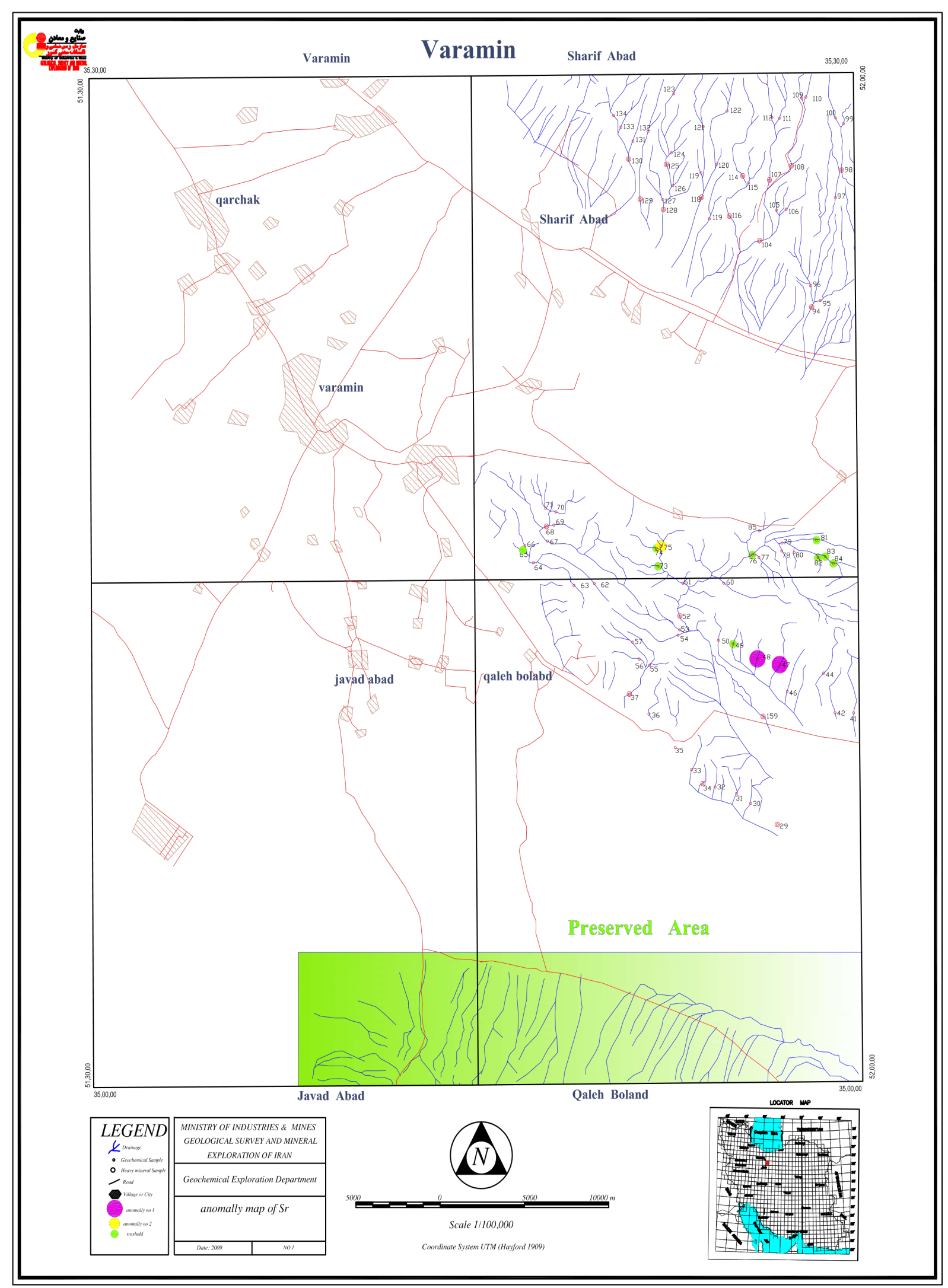

Figure 3. Anomally map of Sr. 


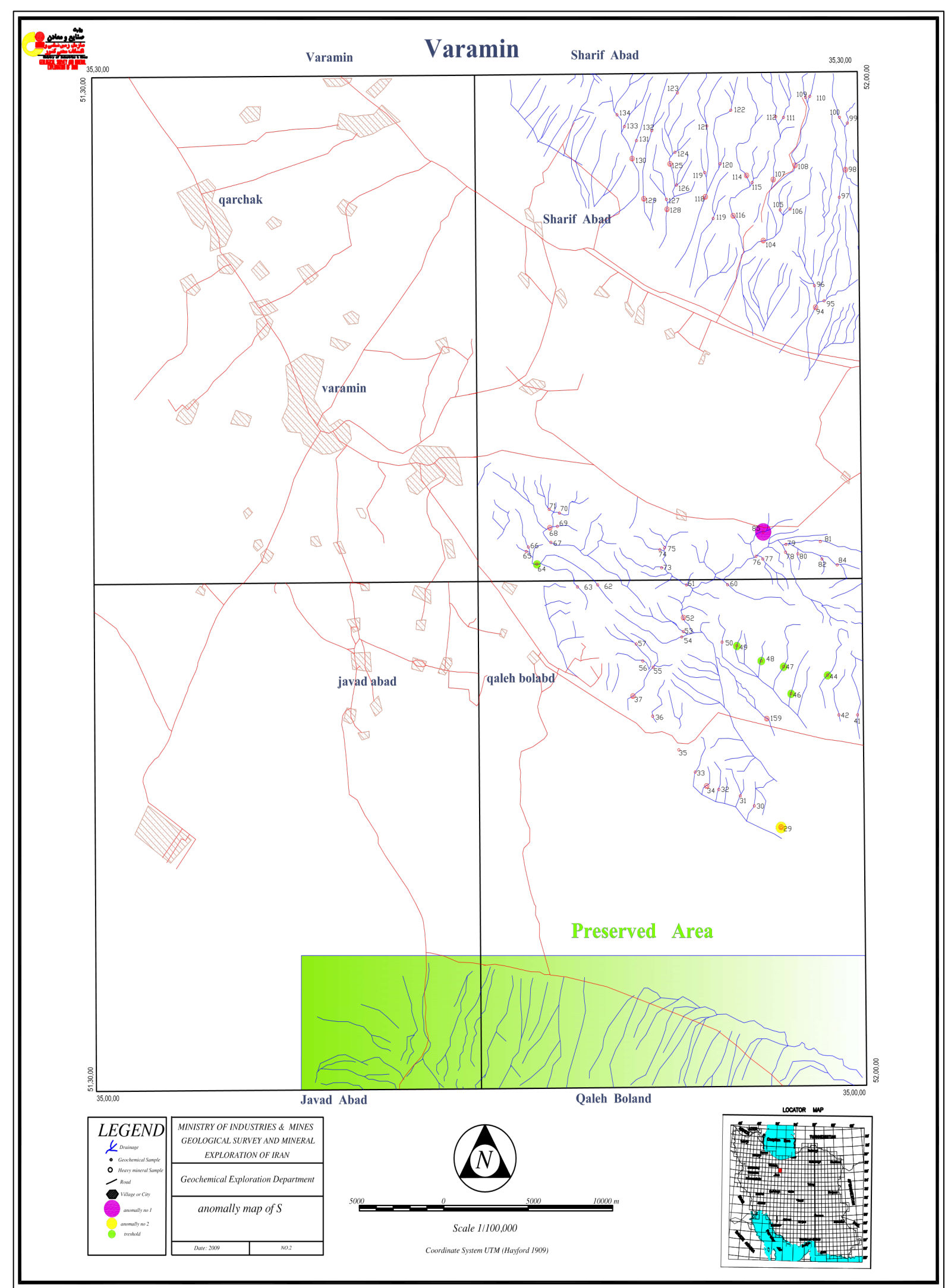

Figure 4. Anomally map of S. 


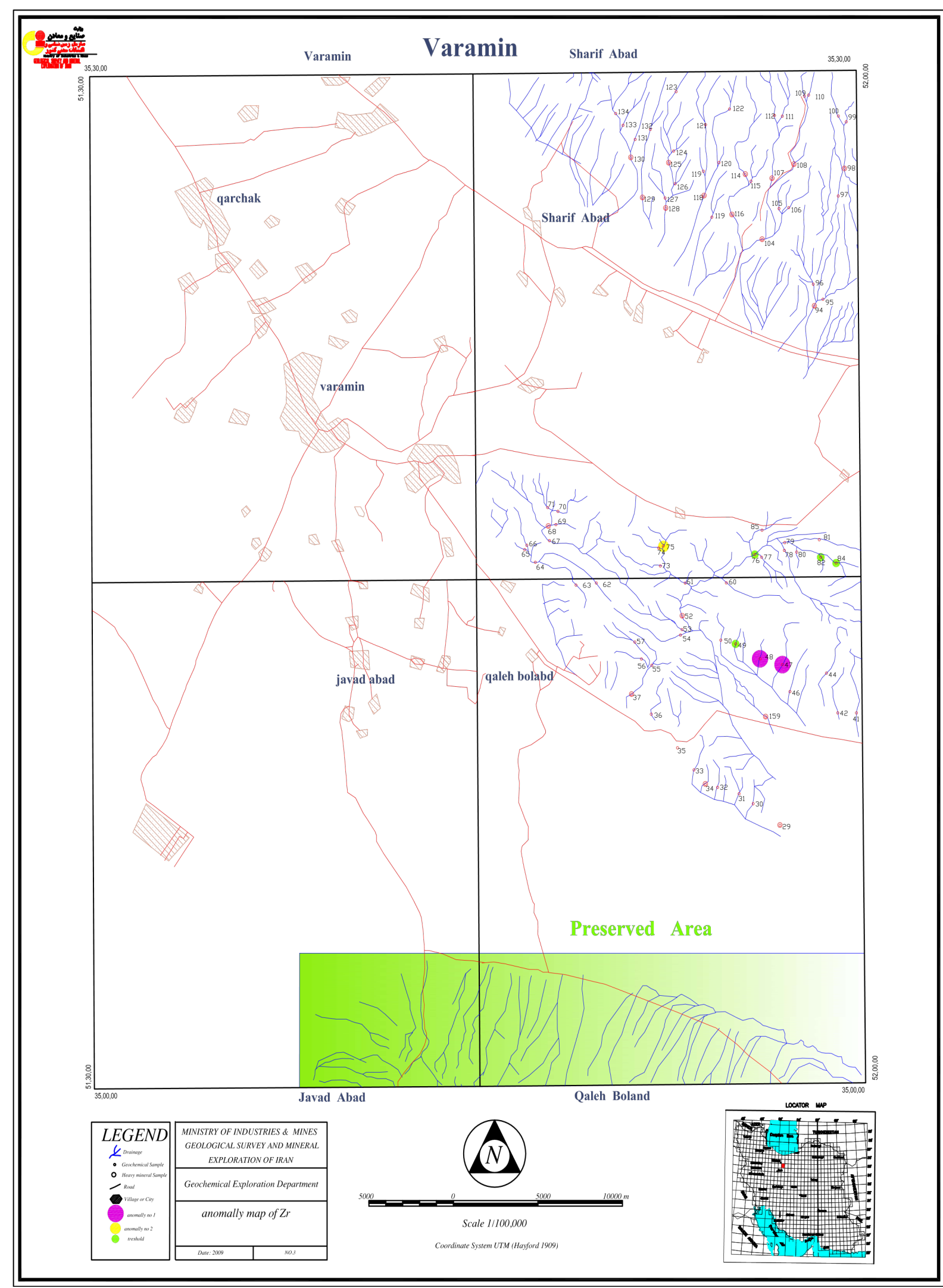

Figure 5. Anomally map of Zr. 


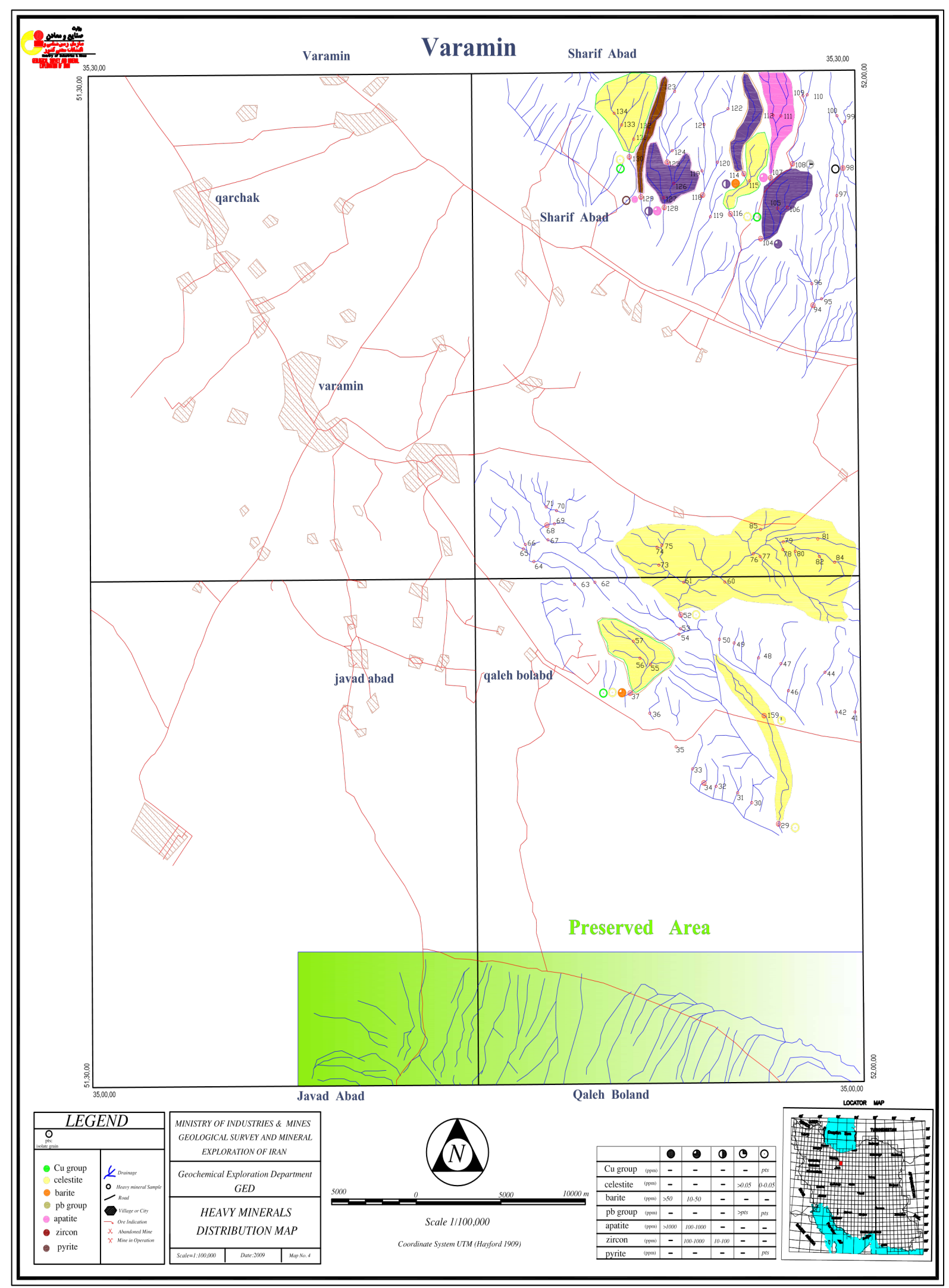

Figure 6. Heavy minerals distribution map. 


\section{Acknowledgements}

The authors thank Eng. Alireza Ashofteh for giving data and for remarkable contribution of this research.

\section{References}

[1] Mohammadi, G. and Ashofteh, A. (2014) Facies and Sedimentary Environment of Cretaceous Units at North West of Dihuk-Tabas Region (Shotori Mountain Range). Journal of Middle East Applied Science and Technology (JMEAST), 6, 148-152.

[2] Mohammadi, G., Gholinejad, M. and Ashofteh, A. (2013) Sedimentology and Sedimentary Environment of Mobarak Formation in Haraz Area-Mobarakabad Village, Iran. Journal of Environmental Treatment Techniques (JETT), 1, 165-167.

[3] Ashofteh, A. and Adib, A. (2015) An Investigation into the Metal Potentials across Bidkhan Area Based on Economic Geological Studies. Open Journal of Geology (OJG), 5, 727-742.

[4] Adib, A. and Ashofteh, A. (2015) Studying Petrology and Determining Tectonic Setting of Bidkhan Rocks Area Southeast of Iran. Open Journal of Geology (OJG), 5, 677-688.

[5] Mohammadi, G. and Ashofteh, A. (2014) Determining of Source Rock and Its Characteristics Using Organic Geo-Chemistry Derived from Parent Rock Evaluation, Separation and Columnar and Gaseous Chromatography on Cretaceous Units in Central Iran at Khor-Biyabanak. European Online Journal of Natural and Social Science (ES), 3, 151-160.

[6] Mohammadi, G. and Ashofteh, A. (2014) Investigation and Usage Sedimentary and Depositioal Environment of Creataceous in South, East of Golpayegan Area. European Online Journal of Natural and Social Science (ES), 3, 179-185.

[7] Mohammadi, G., Pursafari, M. and Ashofteh, A. (2014) The Eocene-Oligocene Facieses and Sedimentary Environments in Sardarreh Area, Garmsar. European Online Journal of Natural and Social Science (ES), 3, 86-94.

[8] Mohammadi, G., Shirzad, M. and Ashofteh, A. (2015) Facies and Sedimentary Environment of the Late Cretaceous Units at Abegarm(avaj) Area. Current World Environment an International (CWE), 10, 771-781.

[9] Mohammadi, G., Batmanghelich, E. and Ashofteh, A. (2015) Investigation of Sedimentology, Sedimentary Environment and Facies of Late Cretaceous in Farahzad Zone North of Mojen Shahroud. Current World Environment an International (CWE), 10, 1060-1071.

\section{Submit or recommend next manuscript to SCIRP and we will provide best service for you:}

Accepting pre-submission inquiries through Email, Facebook, LinkedIn, Twitter, etc.

A wide selection of journals (inclusive of 9 subjects, more than 200 journals)

Providing 24-hour high-quality service

User-friendly online submission system

Fair and swift peer-review system

Efficient typesetting and proofreading procedure

Display of the result of downloads and visits, as well as the number of cited articles

Maximum dissemination of your research work

Submit your manuscript at: http://papersubmission.scirp.org/ 